\title{
Phylogeny of two new pheronematid sponges from the Caroline Seamount and South China Sea
}

\author{
Gong Lin \\ Institute of Oceanology, Chinese Academy of Sciences, Qingdao 266071, China \\ Laboratory for Marine Biology and Biotechnology, Qingdao National Laboratory for \\ Marine Science and Technology, Qingdao 266200, China \\ Center for Ocean Mega-Science, Chinese Academy of Sciences, 7 Nanhai Road, \\ Qingdao 266071, China \\ Graduate University, University of Chinese Academy of Sciences, Beijing 100039, China
}

\author{
LiXinzheng \\ Institute of Oceanology, Chinese Academy of Sciences, Qingdao 266071, China \\ Laboratory for Marine Biology and Biotechnology, Qingdao National Laboratory for \\ Marine Science and Technology, Qingdao 26620o, China \\ Center for Ocean Mega-Science, Chinese Academy of Sciences, 7 Nanhai Road, \\ Qingdao 266071, China \\ Graduate University, University of Chinese Academy of Sciences, Beijing 100039, China \\ lixzh@qdio.ac.cn
}

\section{Lee Kwen-Shen}

Invertebrates Section, Zoology Department, National Museum of Natural Science, 1 Guancian Road, Taichung, Taiwan

\begin{abstract}
Two new species of genus Pheronemoides are described in this study. The Specimens were collected from the South China sea and the Caroline seamount in the northwestern Pacific Ocean. Pheronemoides crustiformis sp. nov. differs from its congeners in exhibiting large microamphidiscs, whip-like and slightly bent microuncinates and small spiny microdiactins. Pheronemoides curvipentactin sp. nov. possesses special pentactine atrialia with round terminal or tapering terminal curved pinular rays and crooked pentactins, making it easily distinguishable from its congeners. Partial sequences of the $28 \mathrm{~S}$ rDNA and $16 \mathrm{~S}$ rDNA genes were also amplified to confirm the family assignment of the two new species and to explore the systematic status of Pheronemoides.
\end{abstract}

(C) LIN ET AL., 2019 | DOI:10.1163/18759866-20191422

This is an open access article distributed under the terms of the CC-BY 4.o License. 


\section{Keywords}

Caroline seamount - Pheronemoides crustiformis sp. nov - Pheronemoides curvipentactin sp. nov phylogeny - South China Sea

\section{Introduction}

Seven genera (Schulzeviella Tabachnick, 1990; Semperella Gray, 1868; Pheronema Leidy, 1868; Platylistrum Schulze, 1904; Poliopogon Thomson, 1877; Sericolophus Ijima, 1901; Pheronemoides Gong \& $\mathrm{Li}, 2017$ ) are included in the family Pheronematidae. Pheronemoides Gong \& Li, 2017 was established based on a single specimen collected on a seamount near Yap Trench. The atrial areas and dermal areas of Pheronemoides are on opposite sides of the body. Its basalia are not positioned exactly at the centre of the body, but rather in a basal crescent and amesially on the dermal surface. Viewed from above, the sponge is hemispherical or spherical. Observed laterally on one side, the sponge is arched and hollow inside (Gong \& Li, 2017). Considering the body shape of the sponge together with the location of the basalia and the marginalia, it may be a transitional genus between Pheronema and Sericolophus.

In July 2016, a sponge specimen was collected at the Taitung County using an Agassiz trawl $121^{\circ} 32.621^{\prime}$ to $121^{\circ} 33.7489^{\prime}$ E longitude and $21^{\circ} 12.4106^{\prime}$ to $21^{\circ} 13.2041^{\prime} \mathrm{N}$ latitude. This is the first report of the presence of Pheronemoides species in the South China Sea. In August 2017, a seamount biodiversity survey on the Caroline seamount was conducted using the $\mathrm{R} / \mathrm{V}$ Ke Xue. Another specimen of Pheronemoides was collected by the remotely operated vehicle (ROV) Fa Xian at a depth of 1429.2 $\mathrm{m}$. After further morphological examination and molecular analysis, the specimens were confirmed to be new species. These two new species are described and illustrated herein. There are now three species in Pheronemoides, all of which were collected in the northwestern Pacific Ocean, two of them were found on seamounts.

\section{Materials and methods}

\section{Sample collection}

One sponge sample was collected by the research ship Ocean Researcher I in the South China Sea using an Agassiz trawl. The sample was deposited in the National Museum of Natural Science, Taiwan. Another sponge sample was collected by the submersible remotely operated vehicle $\mathrm{Fa}$ Xian during a cruise of the research ship KeXue in the western Pacific Ocean. The sample was deposited in the Marine Biological Museum of Chinese Academy of Sciences (MBMCAS), Qingdao, China.

\section{Spicule analysis}

A small piece of sponge tissue was used to prepare the spicules by digesting them with concentrated nitric acid, and the spicules were then observed with scanning electron microscopy (SEM) and light microscopy (LM). For SEM, the spicules were first concentrated on a cover glass (diameter: $8 \mathrm{~mm}$ ), which was then attached to a SEM stub. After coating with gold, the spicules were observed using a Hitachi S-340oN. For spicule measurements, we used an Olympus DSX 500 Optodigital microscope with the manufacturer's image analysis software.

\section{DNA extraction and PCR amplification}

Total genomic DNA was extracted using a Tissue DNA Kit (OMEGA Qingdao, China). Polymerase chain reaction (PCR) amplification 
was carried out in a $25 \mu \mathrm{L}$ total reaction volume containing $12.5 \mu \mathrm{L}$ of Premix Taq $^{\text {TM }}$ (Takara, Otsu, Shiga, Japan), $1 \mu \mathrm{L}$ of each primer, $2 \mu \mathrm{L}$ of template DNA, and $8.5 \mu \mathrm{L}$ of DNase-free $\mathrm{ddH}_{2} \mathrm{O}$. The $16 \mathrm{~S}$ rDNA and $28 \mathrm{~S}$ rDNA sequences were amplified with the primers 16Sifw/16SH_mod (Dohrmann et al., 2008) and 28SliF1(5'-GGCGAAAGACTAATCGAACCA-3')/28SliR1(5'-TTGGAGACCTGATGCGGTGA-3') respectively. Amplification was performed using the following procedure: 5 min at $94^{\circ} \mathrm{C}$ for initial denaturing, followed by 30 cycles of denaturation for $30 \mathrm{~s}$ at $94^{\circ} \mathrm{C}$, annealing for $30 \mathrm{~s}$ at $48^{\circ} \mathrm{C}$, extension for $60 \mathrm{~s}$ at $72^{\circ} \mathrm{C}$, and a final extension for $5 \mathrm{~min}$ at $72^{\circ} \mathrm{C}$.

\section{Phylogenetic analysis}

Analysis based on 16S rDNA and 28S rDNA gene sequences were undertaken to show the systematic status of the two new species as well as the genus Pheronemoides within the family Pheronematidae. The sequence of eight additional species from six genera including all species in Pheronematidae and Hyalonema (Onconema) obtusum as the outgroup were downloaded from GenBank to construct the phylogenetic tree (table 1).

After trimming, the concatenated dataset consisted of $1535 \mathrm{bp}(16 \mathrm{~S} / 28 \mathrm{~S}=417 / 1118 \mathrm{bp})$, alignment gaps were represented as '-' and missing data were represented as '?. The homologous sequences, including ten sequences of $16 \mathrm{~S}$ rDNA and eight sequences of $28 \mathrm{~S}$ rDNA genes, were aligned using MUSCLE 3.8 (Edgar, 2004) with the default parameters. The bestfitting nucleotide substitution model (16S rDNA: GTR+G; $28 \mathrm{~S}$ rDNA: GTR+G) for each partitioned dataset was assessed with ModelTest 3.7 (Posada \& Crandall, 1998). Maximum likelihood (ML) analysis was carried out using RAxMLGUI v1.5 (Silvestro \& Michalak, 2012) under the GTRGAMMA substitution model for all partitions in the concatenated dataset. Bayesian inference (BI) analysis was conducted using Mrbayes 3.2 (Huelsenbeck
\& Ronquist, 2001), Markov Chains were run for 10 million generations, with sampling every 1000 generations. The first $25 \%$ of trees were discarded as burn-in, and the remaining trees were summarized in 50\% majority rule consensus tree to estimate the posterior probabilities. The effective sample size values were examined with Tracer v1.7 (Rambaut et al., 2018) to ensure that convergence was reached.

\section{Results}

\section{Taxonomy}

Class Hexactinellida Schmidt, 1870

Subclass Amphidiscophora Schulze, 1886

Order Amphidiscosida Schrammen, 1924

Family Pheronematidae Gray, 1870

Genus Pheronemoides Gong \& Li, 2017

Pheronemoides crustiformis sp. nov.

(figs. 1-2, table 2)

Material examined. Holotype: MBM286618, Caroline seamount $\left(10^{\circ} 31^{\prime} 29.881^{\prime \prime} \mathrm{N}, 140^{\circ} 11^{\prime} 00\right.$. 083"E), 24 August 2017, 1429.2 m depth, hard bottom.

Description. The sponge is irregularly trapezoidal when observed from above (fig. 1B), the diameter of the body is $530 \mathrm{~mm}$, and the height of the body is $354 \mathrm{~mm}$. It is fan-shaped and has a large hollow between the dermal surface and basalia when viewed from one side (fig. 1A). When viewed from another side, it is spherical. Atrial areas cover the upper surface of the sponge and dermal areas are on the opposite. Marginalia present on the boundary between the atrial and dermal areas, protruding out $20 \mathrm{~mm}$ from the body surface. Basalia are located on the edge of dermal surface as a basal crescent (fig. $1 \mathrm{C}$ ), thus leaving a large hollow between the basalia and dermal areas. Basalia, more than $280 \mathrm{~mm}$ in length, consist of many small spicule tufts. Meshes on atrial areas (of $0.1-1.5 \mathrm{~mm}$ diameter, fig. $1 \mathrm{E}$ ) are 
TABLE 1 Species, specimen museum vouchers, GenBank accession numbers, and references using in this study

\begin{tabular}{|c|c|c|c|c|}
\hline \multirow[t]{2}{*}{ Species } & \multirow[t]{2}{*}{ Vouchers } & \multicolumn{2}{|c|}{ GenBank accession numbers } & \multirow[t]{2}{*}{ References } \\
\hline & & $16 S$ & $28 S$ & \\
\hline $\begin{array}{l}\text { Pheronemoides crustiformis } \\
\text { sp. nov. (holotype) }\end{array}$ & MBM286618 & & MN165729 & This study \\
\hline $\begin{array}{l}\text { Pheronemoides } \\
\text { curvipentactin sp. nov. } \\
\text { (holotype) }\end{array}$ & NMNS-8130-001 & MN165705 & $\mathrm{MN} 165730$ & This study \\
\hline $\begin{array}{l}\text { Pheronemoides fungosus } \\
\text { Gong \& Li, } 2017 \\
\text { (holotype) }\end{array}$ & YM30037 & KU175224 & MN165731 & $\begin{array}{l}\text { Gong et al., 2017; } \\
\text { this study }\end{array}$ \\
\hline Pheronema sp. & & AM886323 & AM886381 & $\begin{array}{l}\text { Dohrmann et al., } \\
2008\end{array}$ \\
\hline $\begin{array}{l}\text { Semperella schulzei } \\
\text { (Semper, 1868) }\end{array}$ & & AM886324 & AM886372 & $\begin{array}{l}\text { Dohrmann et al., } \\
2008\end{array}$ \\
\hline $\begin{array}{l}\text { Semperella jiaolongae } \\
\text { Gong \& Li, } 2015 \text { (holotype) }\end{array}$ & MBM179993 & KM881703 & & Gong et al., 2015 \\
\hline $\begin{array}{l}\text { Sericolophus hawaiicus } \\
\text { Tabachnick \& Lévi, } 2000\end{array}$ & & AM886325 & AM88638o & $\begin{array}{l}\text { Dohrmann et al., } \\
2008\end{array}$ \\
\hline Schulzeviella sp. & $\mathrm{P}_{4-224} \mathrm{sp}_{5}$ & LT627531 & LT627545 & $\begin{array}{l}\text { Dohrmann et al., } \\
2017\end{array}$ \\
\hline $\begin{array}{l}\text { Poliopogon microuncinata } \\
\text { Kersken, Janussen \& } \\
\text { Martínez Arbizu, } 2018\end{array}$ & SMF 11698 & MF683973 & & $\begin{array}{l}\text { Kersken et al., } \\
2018\end{array}$ \\
\hline $\begin{array}{l}\text { Poliopogon distortus } \\
\text { Gong \& Li, } 2018 \text { (holotype) }\end{array}$ & MBM286037 & MFo98799 & & Gong et al., 2018 \\
\hline $\begin{array}{l}\text { Hyalonema (Onconema) } \\
\text { obtusum Lendenfeld, } 1915\end{array}$ & SMF 12072 & MF683971 & MF684003 & $\begin{array}{l}\text { Kersken et al., } \\
2018\end{array}$ \\
\hline
\end{tabular}

wider than dermal areas (of 0.1-1 mm diameter, fig. $1 \mathrm{D})$.

Spicules. Pentactins (fig. 2A) with smooth rays make up the choanosomal skeleton, and tangential rays are $969-5499 \mu \mathrm{m}$ long. Dermal pinular pentactins (fig. 2D) and atrial pentactins (fig. $2 \mathrm{C}$ ) are similar in shape, and the tangential rays, which are slightly spiny, are 75-144 $\mu \mathrm{m}$ and 66-186 $\mu \mathrm{m}$ in length, respectively. Pinular rays, with conical or sharply pointed apex, are $189-307 \mu \mathrm{m}$ and $75^{-144}$ $\mu \mathrm{m}$ in length, respectively. Basalia are twotoothed anchors and monaxones (probably diactins). Anchors have spiny shaft in proximal part (fig. 2O) and smooth shaft in distal part (fig. $2 \mathrm{P}$ ), with diameter of $402-506 \mu \mathrm{m}$ and length can be more than ten centimeters. Monaxones are easily broken and none of a complete one was observed, we speculate that they are diactins. Marginalia are sceptres (length: 3091-8120 $\mu \mathrm{m}$; width: 16-34 $\mu \mathrm{m}$ ) with spiny proximal part and smooth distal part 


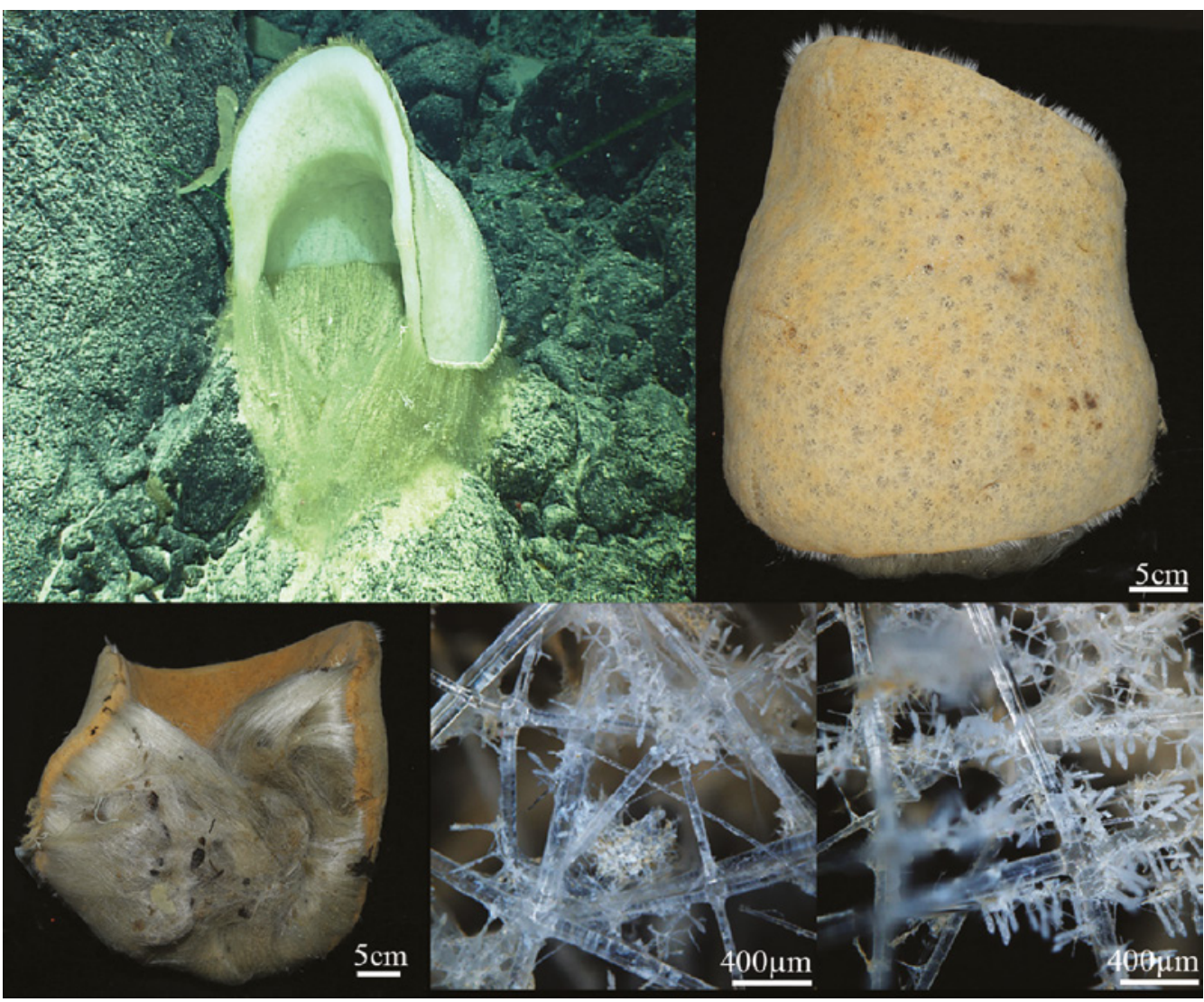

FIGURE 1 Holotype MBM286618 of Pheronemoides crustiformis sp. nov. A, photograph showing the specimen in its natural habitat; B, the external morphology of atrial areas; C, the external morphology of dermal areas and basalia; D, mesh structure of dermal areas; E, mesh structure of atrial areas.

(fig. 2 L-N). Uncinates consist of two types. Macrouncinates (fig. 2J) and mesouncinates (fig. $2 \mathrm{~K}$ ) are similar in shape, and are both covered with numerous short spines. Macrouncinates and mesouncinates are $5182-5873 \mu \mathrm{m}$ and $511-2376 \mu \mathrm{m}$ in length, respectively.

Microscleres consist of microamphidiscs and microdiactins. Microamphidiscs (fig. $2 \mathrm{E}-\mathrm{G}$ ), with palmate head $33 \%$ of the total length, have shafts covered by numerous spines. Total length of microamphidiscs are 23.2-37.8 $\mu \mathrm{m}$, umbel length are $18-28 \mu \mathrm{m}$, and umbel width are $13^{-27} \mu \mathrm{m}$. Microdiactins have two types. Microdiactins I (fig. $2 \mathrm{H}$ ) are whiplike in shape and covered with short spines,
236-367 $\mu \mathrm{m}$ in length. Microdiactins II (fig. 2I) have stronger teeth than microdiactins I, and their total length is $96-177 \mu \mathrm{m}$.

Etymology. Crustiformis is Latin for shellshaped, in reference to the body shape similar to a thin shell viewed from the lateral side of the new specimen.

Remarks. Observed from the lateral side, the new species is arched and hollow inside, and it obviously belongs to Pheronemoides. $P$. crustiformis sp. nov. differs from the $P$. fungosus Gong \& Li, 2017 by having bigger microamphidiscs $(54-86 \mu \mathrm{m}$ versus $23-38 \mu \mathrm{m}$ in $P$. fungosus), a whip-like and slightly bent microuncinate (vs. straight microuncinate 


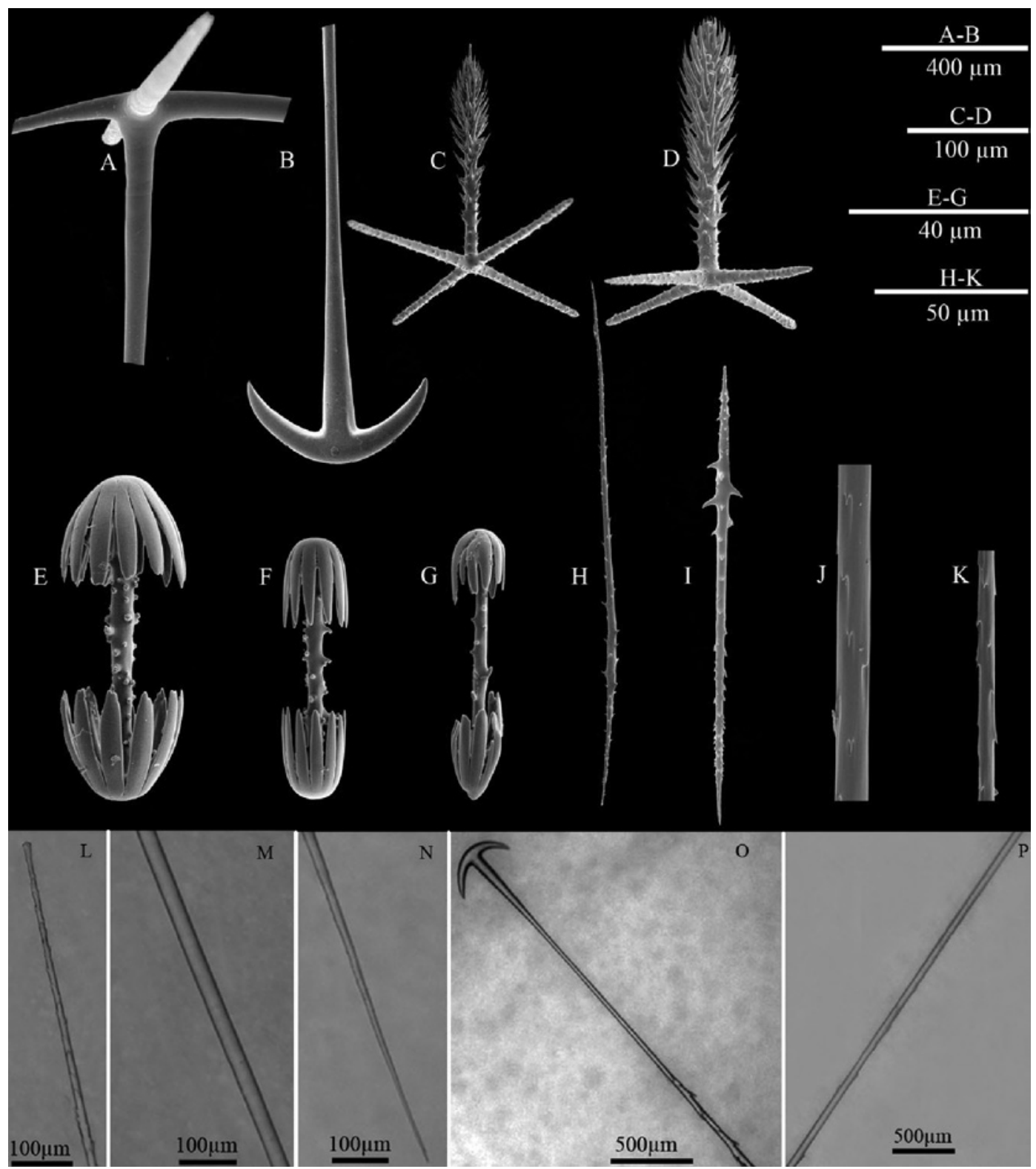

FIGURE 2 Spicules of holotype MBM286618 of Pheronemoides crustiformis sp. nov. A, choanosomal pentactin; B, the anchor of basalia; $C$, atrial pinular pentactin; $D$, dermal pinular pentactin; $\mathrm{E}-\mathrm{G}$, micramphidiscs; $\mathrm{H}$, microdiactin I; I, microdiactin II; J, shaft of macrouncinate; K, shaft of mesouncinate; L-N, Sceptre; $\mathrm{O}-\mathrm{P}$, the anchor of basalia.

in $P$. fungosus), microdiactins covered by hemispherical body shape when observed small spiny teeth (vs. microdiactins covered from above (vs. a spherical body shape in $P$. by long irregular teeth in $P$. fungosus) and a fungosus). 
TABLE 2 Measurements of the spicules of holotype MBM286618 of Pheronemoides crustiformis sp. nov. (in $\mu \mathrm{m}$ ) (n, number of spicules measured; s.d., standard deviation; range, range from the minimum to the maximum)

\begin{tabular}{|c|c|c|c|c|}
\hline & $\mathrm{n}$ & mean & range & s.d. \\
\hline \multicolumn{5}{|l|}{ Dermalia, pinule } \\
\hline pinular ray length & 20 & 238 & $189-307$ & 30 \\
\hline pinular ray width & 20 & 14 & $12-17$ & 2 \\
\hline tangential ray length & 20 & 110 & $75^{-144}$ & 19 \\
\hline tangential ray width & 20 & 10 & $9^{-16}$ & 2 \\
\hline \multicolumn{5}{|l|}{ Atrialia, pinule } \\
\hline pinular ray length & 20 & 214 & 149-309 & 43 \\
\hline pinular ray width & 20 & 12 & $9^{-17}$ & 2 \\
\hline tangential ray length & 20 & 112 & $66-186$ & 29 \\
\hline tangential ray width & 20 & 9 & $7-13$ & 1 \\
\hline \multicolumn{5}{|c|}{ Choanosomalia, pentactin } \\
\hline tangential ray length & 14 & 2643 & $969-5499$ & 1181 \\
\hline tangential ray width & 14 & $3^{8}$ & $25^{-53}$ & 9 \\
\hline \multicolumn{5}{|l|}{ Macrouncinate } \\
\hline length & 3 & 5464 & $5182-5873$ & 362 \\
\hline width & 3 & 20 & $18-23$ & 3 \\
\hline \multicolumn{5}{|l|}{ Mesouncinate } \\
\hline length & 4 & 1881 & $1511-2376$ & 361 \\
\hline width & 4 & 10 & $8-12$ & 1 \\
\hline \multicolumn{5}{|l|}{ Anchor } \\
\hline diameter & 7 & $45^{8}$ & $402-506$ & 35 \\
\hline \multicolumn{5}{|l|}{ Sceptre } \\
\hline length & 6 & $5^{6} 5^{6}$ & $3091-8120$ & 2020 \\
\hline width & 20 & 24 & $16-34$ & 5 \\
\hline \multicolumn{5}{|l|}{ Microdiactin I } \\
\hline length & 17 & 284 & $236-367$ & 39 \\
\hline \multicolumn{5}{|l|}{ Microdiactin II } \\
\hline length & 20 & 139 & 96-177 & 24 \\
\hline \multicolumn{5}{|l|}{ Micramphidisc } \\
\hline length & 20 & 67 & $54-86$ & 8 \\
\hline umbel length & 20 & 22 & $18-28$ & 3 \\
\hline umbel diameter & 20 & 18 & $13^{-27}$ & 3 \\
\hline
\end{tabular}

Pheronemoides curvipentactin sp. nov.

(figs. 3-4, table 3)

Material examined. Holotype: NMNS-8130o01, Lanyu Township, Taitung County, Taiwan,
Pacific Ocean $\left(21^{\mathrm{o}} 13.2041^{\prime} \mathrm{N}, 121^{\circ} 33.7489^{\prime} \mathrm{E}\right), 29$ May 2013, Agassiz trawl, 517m depth.

Description. Specimen is curved (fig. $3 \mathrm{~A}$ ). Dermal surface and atrial surface are on opposite sides. Sponge only has small amount 

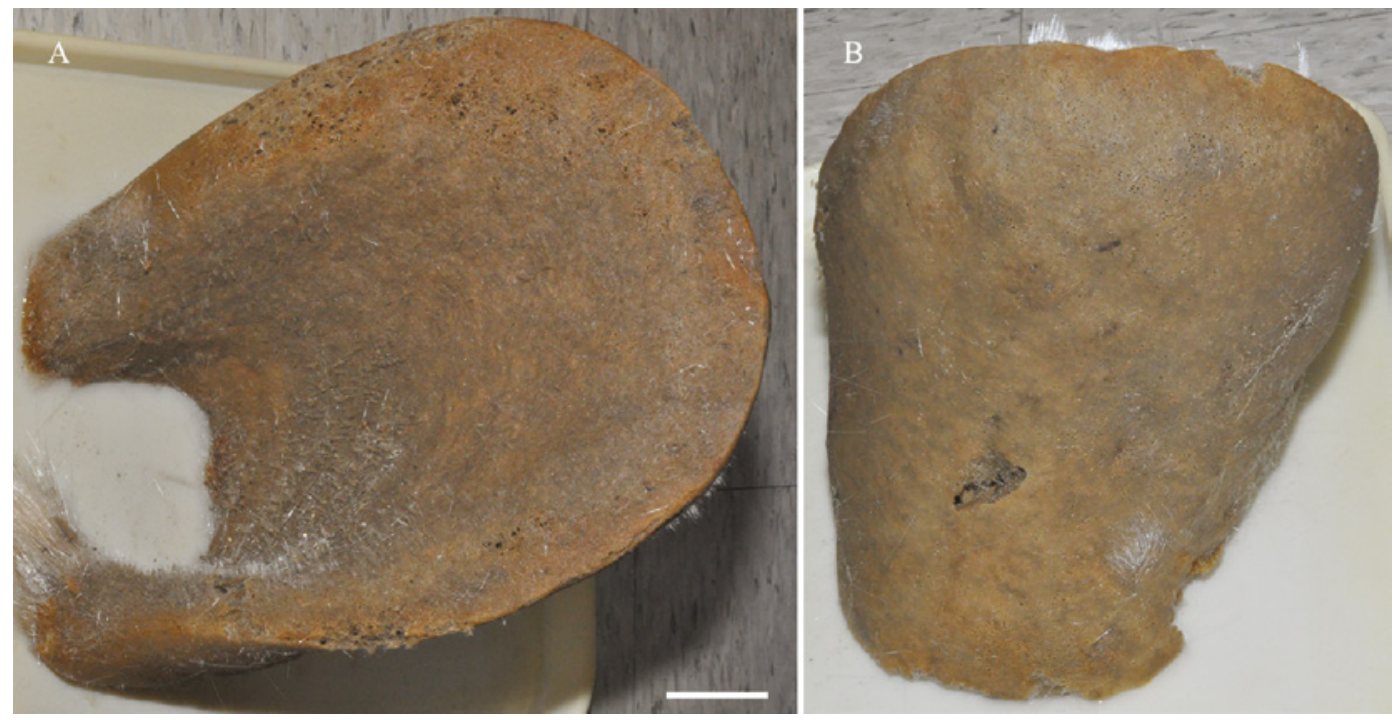

FIGURE 3 Holotype NMNS-8130-001 of Pheronemoides curvipentactin sp. nov. A, the external morphology of dermal areas (scale bar $=5 \mathrm{~cm})$; B, the external morphology of atrial areas.

of basalia left when collected. In addition, there is no available natural living picture of the sponge. From the remaining body shape, we inferred that the sponge has a typical body form of Pheronemoides: when viewed from above, it is fan-shaped (fig. $3 \mathrm{~B}$ ), when viewed from one side, there may be a big hollow between the dermal surface and basalia. The diameter of the sponge is $240 \mathrm{~mm}$. Marginalia are present at the boundary between the atrial and dermal areas, protruding several centimeters from the body surface. Meshes of atrial areas and dermal areas are inconspicuous. Basalia may be located on the dermal surface, and only few basal spicules can be observed.

Spicules. The choanosomal pentactins (fig. 4A) have smooth proximal rays and tangential rays (length: 404-4826 $\mu \mathrm{m}$ ). Dermalia are pinular pentactins (fig. $4 \mathrm{~B}-\mathrm{C}$ ) with tangential rays (length: $89-297 \mu \mathrm{m}$ ) covered with spines and pinular rays (length: $43-77 \mu \mathrm{m}$ ) that are spindle-like and bushy with spines. Atrialiainclude normal and special pentactins. The normal forms (fig. $4 \mathrm{D}-\mathrm{E}$ ) with four spiny tangential rays (length: $177^{-251} \mu \mathrm{m}$ ) and one spindle-like pinular ray (length: $36-63 \mu \mathrm{m}$ ), are slenderer than the dermalia. Atrialia of special form are pentactins which have a sparsely spined pinular ray with round or tapering terminal curved ray (length: $140-261 \mu \mathrm{m}$ ), and four smooth tangential rays (length: 40-124 $\mu \mathrm{m})$ (fig. $4 \mathrm{G}-\mathrm{H}$ ). Crooked pentactins (fig. $4 \mathrm{~F}$ ) with a smooth primary ray, two smooth tangential rays, a curved pinular tangential ray with a large hooked terminus, and a smooth tangential ray with an expanded terminus bearing thin teeth were also observed. This kind of curved pentactin has not been observed in other pheronematid species. Basalia are twotoothed anchors (diameter 364-6o9 $\mu \mathrm{m}$ ) and monaxones (probably diactins). The shaft of anchors are ordered as smooth, spiny, smooth and tapering apex from the proximal part to distal part (fig. $4 \mathrm{O}-\mathrm{Q}$ ). According to marginal spicule of other pheronematida species, though we only observed the shaft and apex of marginalia (fig. $4 \mathrm{R}-\mathrm{S}$ ), we infer that they are probably scepters and/or diactins. The width 


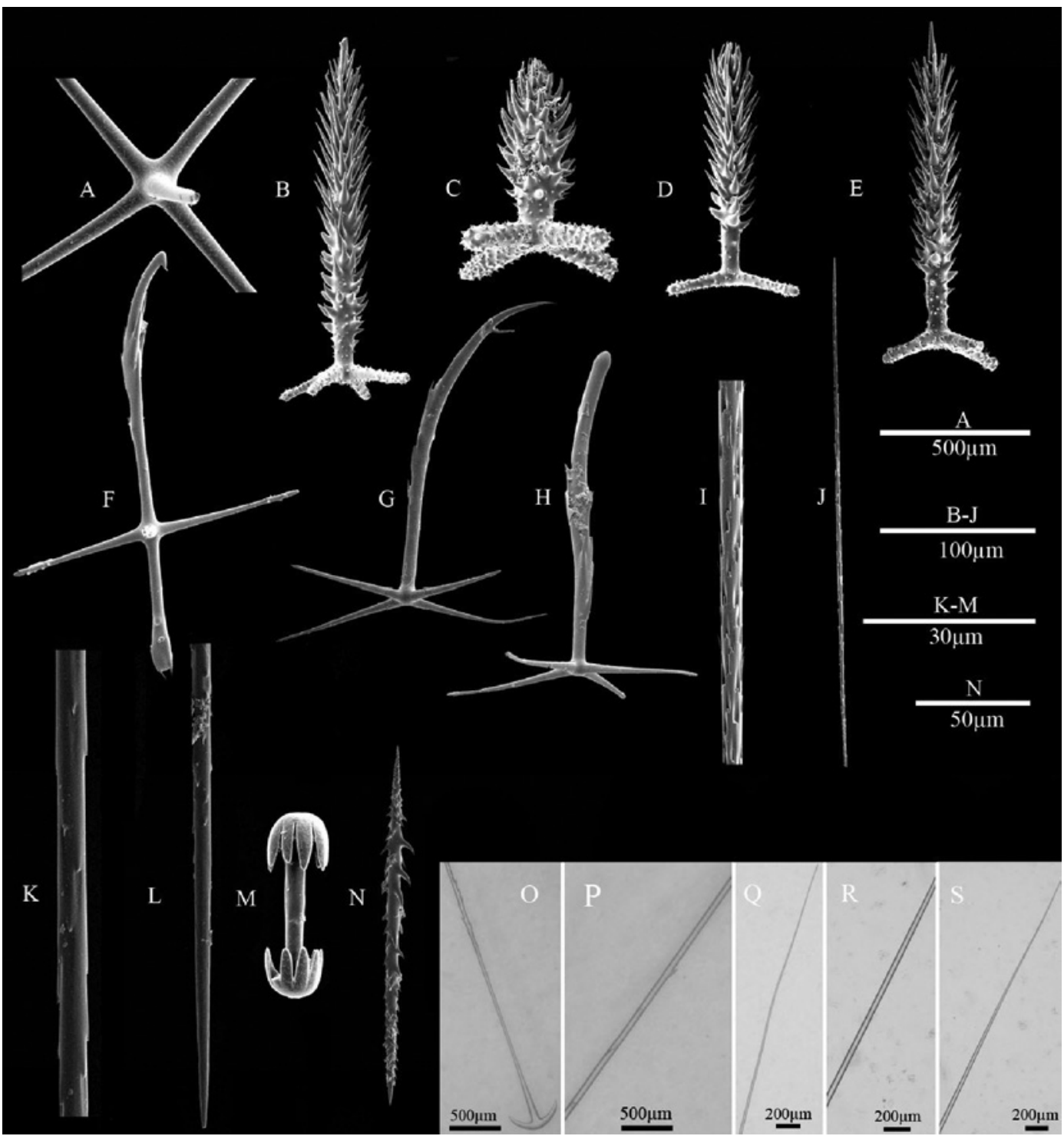

FIGURE 4 Spicules of holotype NMNS-8130-0o1 of Pheronemoides curvipentactin sp. nov. A, choanosomal pentactin; B-C, dermal pinular pentactins; D-H, atrialia: D-E, pinular pentactins; F, crooked pentactin; G-H, special pentactins; I, shaft of macrouncinate; J, microuncinate; $K$, shaft of microuncinate; $L$, terminal of microuncinate; $\mathrm{M}$, micramphidisc; $\mathrm{N}$, microdiactin; $\mathrm{O}-\mathrm{Q}$, the anchor of basalia; R-S; marginalia.

of marginalia are $16-37 \mu \mathrm{m}$. Uncinates are of two types: macrouncinates (fig. $4 \mathrm{I}$ ) and microuncinates (fig. 4J). Macrouncinates (length: $4018-4355 \mu \mathrm{m})$ are covered by many tiny barbs on the shaft. Microuncinates (length: $175^{-366}$ $\mu \mathrm{m})$ are thin with tiny spines on the shaft (fig. $4 \mathrm{~K}$ ) and a sharp terminal (fig. $4 \mathrm{~L}$ ).
Microscleres consist of microamphidiscs and microdiactins. Microamphidiscs (fig. 4M) have smooth shafts, with total length of $27-42$ $\mu \mathrm{m}$, umbel length of 8-10 $\mu \mathrm{m}$ and umbel width of $7-10 \mu \mathrm{m}$. The number of microamphidiscs is small, and their palmate head reprsents 28 $\%$ of the total length. Microdiactins (fig. $4 \mathrm{~N}$ ) 
TABLE 3 Measurements of the spicules of holotype NMNS-8130-001 of Pheronemoides curvipentactin sp. nov. (in $\mu \mathrm{m}$ ) (n, number of spicules measured; s.d., standard deviation; range, range from the minimum to the maximum)

\begin{tabular}{|c|c|c|c|c|}
\hline & $\mathrm{n}$ & mean & range & s.d. \\
\hline \multicolumn{5}{|l|}{ Dermalia, pentactin } \\
\hline pinular ray length & 20 & 122 & $89-297$ & 43 \\
\hline pinular ray width & 20 & 19 & $12-27$ & 4 \\
\hline tangential ray length & 20 & 59 & $43-77$ & 11 \\
\hline tangential ray width & 20 & 12 & $7-15$ & 2 \\
\hline \multicolumn{5}{|l|}{ Atrialia, normal pentactin } \\
\hline pinular ray length & 20 & 216 & $177-251$ & 20 \\
\hline pinular ray width & 20 & 12 & $10-15$ & 1 \\
\hline tangential ray length & 20 & 48 & $36-63$ & 8 \\
\hline tangential ray width & 20 & 8 & $6-11$ & 1 \\
\hline \multicolumn{5}{|l|}{ Atrialia, special pentactin } \\
\hline primary ray length & 15 & 214 & $140-261$ & 30 \\
\hline primary ray width & 15 & 8 & $6-10$ & 1 \\
\hline tangential ray length & 15 & 81 & $40-124$ & 26 \\
\hline tangential ray width & 15 & 6 & $4-7$ & 0.7 \\
\hline \multicolumn{5}{|l|}{ Choanosomalia, pentactin } \\
\hline tangential ray length & 20 & 1550 & $404-4826$ & 1041 \\
\hline tangential ray width & 20 & 24 & $14-38$ & 7 \\
\hline \multicolumn{5}{|l|}{ Macrouncinate } \\
\hline length & 3 & 4182 & $4018-4355$ & 168 \\
\hline width & 3 & 16 & $15^{-17}$ & 1 \\
\hline \multicolumn{5}{|l|}{ Microuncinate } \\
\hline length & 18 & 219 & $175^{-366}$ & 53 \\
\hline \multicolumn{5}{|l|}{ Marginalia } \\
\hline width & 20 & 29 & $16-37$ & 5 \\
\hline \multicolumn{5}{|l|}{ Anchor } \\
\hline length & 6 & 505 & $364-609$ & 85 \\
\hline \multicolumn{5}{|l|}{ Microdiactin } \\
\hline length & 20 & 138 & 118-157 & 15 \\
\hline \multicolumn{5}{|l|}{ Micramphidisc } \\
\hline length & 4 & 32 & $27-42$ & 7 \\
\hline umbel length & 4 & 9 & $8-10$ & 1 \\
\hline umbel diameter & 4 & 9 & $7-10$ & 1 \\
\hline
\end{tabular}

have long teeth and their total length is $118-$ $157 \mu \mathrm{m}$.

Etymology. Curvipentactin from curv (meaning curved), pent (meaning five), and aktis (meaning rays), refers to this species containing curved pentactin spicules.
Remarks. Although the new specimen is incomplete, and a hollow between the atrial and dermal surfaces is not observed, the body is arched, and we can infer that its basalia are not positioned exactly at the centre of the body but amesially on the dermal surface, 


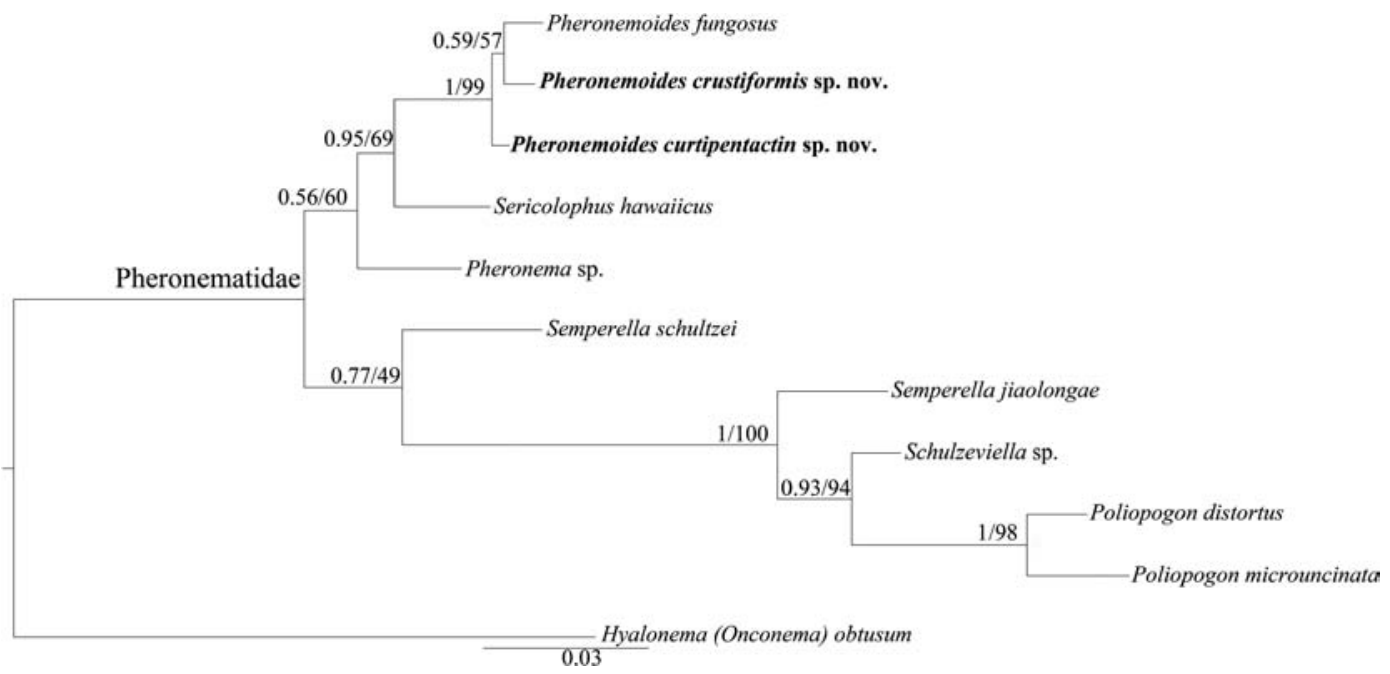

FIGURE 5 Bayesian inference trees of pheronematid species based on the 16S rDNA and 28S rDNA sequence data. Numbers at each node are Bayesian posterior probabilities (left) and ML analysis bootstrap values (right).

Therefore, we infer that the new species belongs to Pheronemoides. The new species can be easily distinguished from its congeners by possessing special pentactine atrialia with round terminal or tapering terminal curved pinular rays and crooked pentactins. Additionally, the new species contains macrouncinates and microuncinates while $P$. fungosus contains three types of uncinates and $P$. crustiformis contains macrouncinates and mesouncinates.

Molecular data. The phylogenies of BI and ML analyses were highly congruent. The phylogeny based on 28SrRNA and 16SrRNA (fig. 5) shows that the two new species and $P$. fungosus forms into a clade with the exclusion of other pheronematids, thus supporting the family assignment, with support values $>50$ for both the ML and BI analyses.

\section{Discussion}

The phylogeny of the family Pheronematidae through molecular approaches had been explored by Kersken's (2018) and Dohrmann's (2018). And they have obtained similar phylogenetic tree. In our study, we added the molecular data of Poliopogon distortus and the two new species, and a more comprehensive tree is provided. Our tree was generally consistent with the previous results except the status of Semperella schulzei which was sister to Semperella jialongae+Poliopogon+Schulz eviella while it was clustered to Pheronema+ Sericolophus+Pheronemoides in the previous studies. This was probably due to the different choices of alignment and substitution models, the molecular sequences of three additional species, as well as one or two reduced molecular markers used in our analysis. Though there were some differences, our tree revealed same relationship among the different genera of Pheronematidae as the previous studies, as well as the genus Semperella was a non-monophyletic group. More species of definitive Semperella are need to be sequenced in further studies to elucidate the status of this genus.

The seven genera of Pheronematidae Gray, 1870 are often distinguished from each 
other mainly by their external body shape, whereas the morphologies and diversity of the spicules are less important (Tabachnick \& Menshenina, 2002). Aproaches on the phylogeny of Pheronematidae based on morphology were explored once (Tabachnick \& Menshenina, 1999; Dohrmann et al., 2017). In our tree, Pheronematidae is divided into two clades. In one clade, Pheronema is sister to Sericolophus + Pheronemoides. This is consistent with Tabachnick et al. (1999), who consider Sericolophus to have evolved independently in relation to Pheronema species, and Gong et al. (2017), who recognized Pheronemoides has a closed relationship with Pheronema and Sericolophus. The other clade included Semperella, Poliopogon and Schulzeviella, which differed from the results of Dohrmann, who inferred that Schulzeviella was the sister group to the remaining pheronematids (Dohrmann et al., 2017). Since the phylogeny based on molecular data was not consist with the morphology-based hypotheses, the special morphology of different genera within Pheronematidae may not be enough to treated as a reliable synapomorphy. And the unique morphological characteristics (i.e., the body being bilaterally symmetrical or not, the atrial cavity being open or closed, atrialia being a common surface or not and basalia in a compact tuft or a broad tuft) used to identify pheronematida species into different genera might need refinement.

Pheronemoides, which is fan-like, exhibit an atrial concave side and a dermal convex side without basalia (fig. 2). It shows a typical body shape similar to Poliopogon species. When we established the genus, there was confusion about whether the genus was effectively defined according to morphological approaches. In our tree, Pheronemoides and Poliopogon are distant, and all the species of Pheronemoides and Poliopogon were grouped together, which proves that Pheronemoides is a valid genus.
P.curvipentactinsp. nov. and P. fungosus exhibit a closer relationship than $P$. crustiformis. Ecologically, $P$. curvipentactin sp. nov. and $P$. fungosus occur at the hard bottom on seamounts in the northwestern Pacific Ocean, while $P$. crustiformis sp. nov. occurs in the South China sea (substrate unknown due to the absence of a natural living image). Morphologically, only $P$. crustiformis sp. nov. exhibits special pentactine atrialia, which makes it is easily distinguished from the others species.

Forty-eight valid species of pheronematid have been reported (Van Soest et al., 2019); here, we only include 6 valid species in our tree (without the two new species and two species that were unable to be classified at the species level). Therefore, more taxon coverage and molecular markers will be needed in future studies to explore the phylogeny of Pheronematidae.

\section{Acknowledgements}

Special thanks to Dr. Kuidong $\mathrm{Xu}$ (Institute of Oceanology, Chinese Academy of Sciences, Qingdao) for providing the deep-sea sponge specimens and the in situ pictures. We are grateful to the crews of the $\mathrm{R} / \mathrm{V} \mathrm{Ke}$ $X u e$ for their support in collecting the deepsea sponge specimens during the cruises. We also thank the editor and the reviewers for helping to improve the manuscript. This work was supported by the National Natural Science Foundation of China (No. 41706188), Science \& Technology Basic Resources Investigation Program of China (No. 2017FY100804), the National Key R\&D Program of China (No. 2018YFCo309804), the Senior User Project of RV KEXUE (No. KEXUE2018G22), the China Ocean Mineral Resources Research and Development Association Program (No. DY135-E2 $-3-04)$. 


\section{References}

Dohrmann, M. (2018) Progress in glass sponge phylogenetics: a comment on Kersken et al (2018). Hydrobiologia. doi:10.1007/s10750-018-3708-7.

Dohrmann, M., Janussen, D., Reitner, J., Collins, A.G. \& Wörheide, G. (2008) Phylogeny and evolution of glass sponges (Porifera, Hexactinellida). Syst. Biol., 57(3), 388-405. doi:10.1080/10635150802161088.

Dohrmann, M., Kelley, C., Kelly, M., Pisera, A., Hooper, J.N. \& Reiswig, H.M (2017) An integrative systematic framework helps to reconstruct skeletal evolution of glass sponges (Porifera, Hexactinellida). Front. Zool., 14, 18. doi:10.1186/ s12983-017-0191-3.

Edgar, R.C. (2004) MUSCLE: multiple sequence alignment with high accuracy and high throughput. Nucleic Acids Res., 32, 1792-1797. doi:10.1093/nar/gkh340.

Gong, L. \& Li, X. (2017) A new genus and species of Pheronematidae (Porifera: Hexactinellida: Amphidiscosida) from the western Pacific Ocean. Zootaxa, 4337(1), 132-140. doi:10.11646/ zootaxa.4337.1.7.

Gong, L., Li, X. \& Qiu, J.W. (2015) Two new species of Hexactinellida (Porifera) from the South China Sea. Zootaxa, 4034(1), 182-192. doi:10.11646/ zootaxa.4034.1.9.

Huelsenbeck, J.P. \& Ronquist, F. (2001) MRBAYES: Bayesian inference of phylogenetic trees. Bioinformatics, 17, 754-755. doi:10.1093/ bioinformatics/17.8.754.

Kersken, D., Kocot, K., Janussen, D., Schell, T., Pfenninger, M. \& Arbizu, P.M. (2018) First insights into the phylogeny of deep-sea glass sponges (Hexactinellida) from polymetallic nodule fields in the Clarion-Clipperton Fracture Zone (CCFZ), northeastern Pacific. Hydrobiologia, 811(1), 283-293. doi:10.1007/s10750-017-3498-3.
Posada, D. \& Crandall, K.A. (1998) ModelTest: testing the model of DNA substitution. Bioinformatics, 14, 817-818. doi:10.1093/ bioinformatics/14.9.817.

Rambaut, A., Drummond, A.J., Xie, D., Baele, G. \& Suchard, M.A. (2018) Posterior summarization in bayesian phylogenetics using tracer 1.7. Syst. Biol., 67(5), 901-904. doi:10.1093/sysbio/syyo32. Silvestro, D. \& Michalak, I. (2012) raxmlGUI: a graphical front-end for RAxML. Org. Divers. Evol., 12, 335-337. doi:10.1007/s13127-011-0056-0.

Tabachnick, K.R. \& Menshenina, L.L. (1999) An approach to the phylogenetic reconstruction of Amphidiscophora (Porifera: Hexactinellida). Mem. Queensl. Mus., 44, 607-615.

Tabachnick, K.R. \& Menshenina, L.L. (2002) Family Pheronematidae Gray, 1870. In:J.N.A. Hooper \& R.W.M. Van Soest (Eds) Systema Porifera. A guide to the Classification of Sponges, pp. 12671280. Kluwer Academic/Plenum Publishers, New York. doi:10.1007/978-1-4615-0747-5_129.

Van Soest, R.W.M., Boury-Esnault, N., Hooper,J.N.A., Rützler, K., de Voogd, N.J., Alvarez, B., Hajdu, E., Pisera, A.B., Manconi, R., Schönberg, C., Klautau, M., Picton, B., Kelly, M., Vacelet, J., Dohrmann, M., Díaz, M.C., Cárdenas, P., Carballo, J.L., Ríos, P. \& Downey, R. (2019) World Porifera Database. Pheronematidae Gray, 1870. Accessed online on 9 July 2019: http://www.marinespecies.org/ aphia.php? $\mathrm{p}=$ taxdetails $\&$ id $=131685$

RECEIVED: 2 AUGUST 2019 | REVISED AND ACCEPTED: 27 SEPTEMBER 2019

EDITOR: R. VAN SOEST 